\title{
Imatinib Enhances Docetaxel-Induced Apoptosis Through Inhibition of Nuclear Factor- $\kappa$ B Activation in Anaplastic Thyroid Carcinoma Cells
}

\author{
EunSook Kim, ${ }^{1,2, *}$ Michiko Matsuse, ${ }^{1, *}$ Vladimir Saenko, ${ }^{3}$ Keiji Suzuki, ${ }^{1}$ Akira Ohtsuru, ${ }^{4}$ \\ Norisato Mitsutake, ${ }^{1,5}$ and Shunichi Yamashita ${ }^{1,2,4}$
}

Background: We previously reported the partial effectiveness of imatinib (also known as STI571, Glivec, or Gleevec) on anaplastic thyroid cancer (ATC) cells. Imatinib is a selective tyrosine kinase inhibitor that has been used for various types of cancer treatments. Recently, several reports have demonstrated that imatinib enhanced the sensitivity of cancer cells to other anticancer drugs. In this study, therefore, we investigated whether imatinib enhances the antitumor activity of docetaxel in ATC cells.

Methods: Two ATC cell lines, FRO and KTC-2, were treated with imatinib and/or docetaxel. Cell survival assay and flow cytometry for annexin $\mathrm{V}$ were used to assess the induction of apoptosis. Changes of pro- and antiapoptotic factors were determined by Western blot. Nuclear factor- $\kappa$ B (NF- $\kappa$ B) activity was measured by DNAbinding assay. Tumor growth was also investigated in vivo.

Results: The combined treatment significantly enhanced apoptosis compared with single treatment. ATC cells themselves expressed high levels of antiapoptotic factors, X-linked inhibitor of apoptosis (XIAP), and survivin. The treatment with docetaxel alone further increased their expressions; however, the combined treatment blocked the inductions. Although imatinib alone had no effect on NF- $\kappa$ B background levels, combined treatment significantly suppressed the docetaxel-induced NF- $\kappa$ B activation. Further, the combined administration of the drugs also showed significantly greater inhibitory effect on tumor growth in mice xenograft model.

Conclusions: Imatinib enhanced antitumor activity of docetaxel in ATC cells. Docetaxel seemed to induce both pro- and antiapoptotic signaling pathways in ATC cells, and imatinib blocked the antiapoptotic signal. Thus, docetaxel combined with imatinib emerges as an attractive strategy for the treatment of ATC.

\section{Introduction}

A NAPLASTIC THYROID CANCER (ATC) is one of the most aggressive human malignant tumors. Multidisciplinary treatments, including radio- and chemotherapies, still poorly control the progression of this disease, and its mean survival is less than one year after initial diagnosis (1). Therefore, there is a critical need to develop a novel approach to treat patients with ATC.

Docetaxel is an anticancer microtubule-stabilizing agent that induces apoptosis by suppressing the microtubule dy- namics of mitotic apparatus. Docetaxel also arrests cells in G2/M phase, leading to increase of sensitivity of cancer cells to radio- and chemotherapies (2-4). Although the effect of the drug alone was only modest against ATC in a clinical trial (5), combined therapy with radiation and/or another type of drug may be effective (6-8).

Imatinib (also known as STI571, Glivec, or Gleevec) is a selective tyrosine kinase inhibitor and was originally developed to inhibit BCR/ABL fusion oncoprotein expressed in chronic myelogenous leukemia (CML). It also cross-reacts with other tyrosine kinases, such as c-ABL, c-KIT, and

Departments of ${ }^{1}$ Radiation Medical Sciences and ${ }^{3}$ Health Risk Control, Atomic Bomb Disease Institute, Nagasaki University Graduate School of Biomedical Sciences, Nagasaki, Japan.

${ }^{2}$ Department of Internal Medicine, Biomedical Research Center, Ulsan University Hospital, University of Ulsan College of Medicine, Ulsan, Korea.

${ }^{4}$ Takashi Nagai Memorial International Hibakusha Medical Center, Nagasaki University Hospital, Nagasaki, Japan.

${ }^{5}$ Nagasaki University Research Center for Genomic Instability and Carcinogenesis (NRGIC), Nagasaki, Japan.

*These authors contributed equally to this work. 
platelet-derived growth factor receptors (PDGFRs), and has been used for the treatment of gastrointestinal stromal tumor, small cell lung cancer, ovarian cancer, and colorectal carcinoma (9-13). In preclinical cancer models, we have already reported the partial effectiveness of imatinib on ATC cells (14). We have also demonstrated that imatinib combined with ionizing radiation enhanced senescence-like growth arrest (SLGA) (15). Very recently, a clinical trial using imatinib as a single agent for the treatment of ATC has shown weak responses: no complete response, $25 \%$ partial response, and $50 \%$ stable disease at 8 weeks, but the rate of 6-month survival was only $45 \%$ (16).

Several reports have demonstrated that imatinib enhanced the sensitivity of various cancer cells to anticancer drugs $(9,17)$. A few studies have investigated the anticancer efficacy of imatinib/docetaxel combinations in preclinical models. It was shown that the combination of imatinib and docetaxel was significantly more effective than either agent alone in the nonsmall cell lung carcinoma xenograft model. In this model, imatinib, as an inhibitor of PDGFR $\beta$, decreased microvessel density and interstitial fluid pressure, and thereby improved subsequent delivery of docetaxel (18). Another report showed that in human CML cells, the imatinib/docetaxel combination induced apoptosis through decreasing mitochondrial membrane potential and increasing caspase-3 enzyme activity (19). Kinsella et al. reported that imatinib combined with docetaxel strongly inhibited both proliferation and invasion, and had a proapoptotic effect in glioma cells (20). So far, there has been no report regarding the therapeutic efficacy of imatinib/ docetaxel combinations in ATC.

In this study, we demonstrate that imatinib enhanced the antitumor activity of docetaxel in ATC cells. Docetaxel seemed to induce both proapoptotic and antiapoptotic signaling pathways, and imatinib blocked the antiapoptotic signal through inhibition of docetaxel-induced nuclear factor$\kappa \mathrm{B}(\mathrm{NF}-\kappa \mathrm{B})$ activation.

\section{Methods}

\section{Reagents}

Imatinib (Novartis, Basel, Switzerland) was dissolved in dimethyl sulfoxide (DMSO) at stock concentration of $7 \mathrm{mM}$ for in vitro experiments, and for in vivo experiments, imatinib tablets were dissolved in distilled water, and insoluble material was removed by repeated centrifugation at $2500 \mathrm{~g}$ as described previously (21). Docetaxel (Wako Chemicals, Osa$\mathrm{ka}$, Japan) was dissolved in DMSO at a stock concentration of $1 \mathrm{mM}$. The antibodies to $\mathrm{p} 65$, survivin, and $\beta$-actin were obtained from Santa Cruz Biotechnology (Santa Cruz, CA); the antibodies to X-linked inhibitor of apoptosis (XIAP), cleaved caspase-3, poly (ADP-ribose) polymerase (PARP), I $\kappa \mathrm{B} \alpha[\mathrm{nu}-$ clear factor of kappa light polypeptide gene enhancer in B-cells inhibitor, alpha], and antirabbit and antimouse horseradish peroxidase-conjugated antibodies were from Cell Signaling Technology (Beverly, MA).

\section{Cell culture}

The human ATC cell line FRO was originally provided by Dr. James A. Fagin (University of Cincinnati College of Medicine, Cincinnati, OH; currently Memorial Sloan-Kettering Cancer Center, New York, NY), and KTC-2 was from
Dr. Kurebayashi (Kawasaki Medical School, Kurashiki, Japan) (22). All cells were grown in RPMI 1640 (Wako Chemicals) supplemented with $5 \%(\mathrm{v} / \mathrm{v})$ fetal bovine serum and $1 \%(\mathrm{w} / \mathrm{v})$ penicillin/streptomycin (Wako Chemicals).

\section{Cell growth assay}

Cells were seeded onto each well of 24 -well plate (500 $\mu \mathrm{L}$, $15 \times 10^{3}$ cells per well) and incubated for 24 hours before treatment. Solutions containing various concentrations of docetaxel and/or imatinib were added to each well in $55 \mu \mathrm{L}$ medium, with three wells used for each concentration. In the control wells, DMSO was added. The final concentration of DMSO in any well did not exceed $0.2 \%(\mathrm{v} / \mathrm{v})$. After incubation, the number of cells were counted with a Coulter counter (Beckman Coulter, Fuller, CA).

\section{Flow cytometry analysis with the annexin V/PI staining}

Detection of apoptotic cells was performed with an Annexin V-PI apoptosis detection kit (Wako Chemicals) according to the manufacturer's instructions. In brief, $4 \times 10^{5}$ cells were double stained with fluorescein isothiocyanateconjugated annexin $\mathrm{V}$ and propidium iodide (PI) for $15 \mathrm{~min}$ at room temperature in a $\mathrm{Ca}^{2+}$-enriched binding buffer and then analyzed on an FACS Vantage SE (BD Biosciences, San Jose, $\mathrm{CA})$. Fluorescein isothiocyanate and PI emissions were detected in the FL- 1 and FL-3 channels, respectively. Analysis was done with Cell Quest software (BD Biosciences).

\section{Senescence-associated $\beta$-galactosidase staining}

Senescence-associated $\beta$-gal staining (SA- $\beta$-gal) was performed as described elsewhere (23). Briefly, after experimental treatment, cells on plates were fixed with $2 \%(\mathrm{v} / \mathrm{v})$ formaldehyde $/ 0.2 \%(\mathrm{v} / \mathrm{v})$ glutaraldehyde, washed with phosphate-buffered saline, and assayed for SA- $\beta$-gal activity using X-gal (5-bromo-4-chloro-3-indolyl $\beta$-D-galactosidase) at $\mathrm{pH}$ 6.0. SA- $\beta$-gal ${ }^{+}$cells were detected by bright-field microscopy.

\section{Western blotting}

Forty micrograms of protein was separated with sodium dodecyl sulfate-polyacrylamide gel electrophoresis and transferred onto polyvinylidene difluoride membranes (Millipore Corp., Bedford, MA). After incubation with an appropriate primary antibody, the antigen-antibody complexes were visualized using horseradish peroxidase-conjugated secondary antibody and a chemiluminescence system (NacalaiTesque, Kyoto, Japan). Detection was performed using an LAS3000 imaging system (FUJIFILM, Tokyo, Japan).

\section{DNA-binding assay}

The multiwell colorimetric assay for active NF- $\kappa \mathrm{B}$ was performed as described previously (24). Briefly, equal amount of nuclear extracts was incubated in 96-well plate coated with immobilized oligonucleotide containing a NF- $\kappa \mathrm{B}$ consensus binding site. NF- $\kappa$ B binding to the target oligonucleotide was detected with primary antibody specific for p65 subunit and horseradish peroxidase-conjugated secondary antibody. For quantification of activity, optical densities (ODs) were measured at $450 \mathrm{~nm}$ using a microplate reader 2030 ARVO X (Perkin Elmer, Inc., Waltham, MA). 


\section{In vivo xenograft model}

All mice were maintained at Nagasaki University animal facility, and all animal experiments described in this study were conducted in accordance with the principles and procedures outlined in the Guide for the Care and Use of Laboratory Animals of Nagasaki University. FRO cells $\left(3 \times 10^{6}\right)$ resuspended in RPMI 1640 were injected subcutaneously into both flanks of 6-week-old male BALB/c nu/nu mice (CLEA Japan, Tokyo, Japan), five animals per group. Then, they were randomly assigned into four groups. The tumor sizes were measured every 3 days with calipers, and tumor volumes were calculated according to the formula, $a^{2} \times b \times 0.4$, where $a$ is the smallest tumor diameter and $b$ is the diameter perpendicular to $a$. Imatinib solution in sterile water/phosphatebuffered saline (ratio 1:1) was injected intraperitoneally (i.p.) daily for 2 weeks at a dose of $50 \mathrm{mg} / \mathrm{kg}$ beginning from day 9 after tumor implantation. Docetaxel, diluted in phosphatebuffered saline/DMSO (ratio 1:1), was injected i.p. at a dose of $5 \mathrm{mg} / \mathrm{kg}$ on days 9 and 16 . Combined treatment mice were given both drugs. Control group mice received vehicle injections only. For 27 days, tumor size was monitored, and body weight, feeding behavior, and motor activity of each animal were monitored as indicators of general health.

\section{Statistical analysis}

All data were expressed as the mean \pm standard deviation. Differences between groups were examined for statistical significance with analysis of variance followed by Tukey's posttest. A $p$-value not exceeding 0.05 was considered statistically significant.

\section{Results}

\section{Inhibition of cell growth by docetaxel and/or imatinib}

To investigate the effect of docetaxel and/or imatinib, cell growth assays were done. Our previous experiments $(7,14)$ (unpublished data, Michiko Matsuse, Nagasaki University, 2008) demonstrated that moderate cell growth inhibition by imatinib and docetaxel was observed at concentrations of $7 \mu \mathrm{M}$ and $1-2 \mathrm{nM}$ in FRO cells, respectively. Thus, we conducted the experiments using $7 \mu \mathrm{M}$ of imatinib and $1 \mathrm{nM}$ of docetaxel. As shown in Fig. 1, both docetaxel and imatinib had a moderate inhibitory effect on the growth of FRO cells, and combined treatment significantly reduced the cell number compared with single treatment (Fig. 1). We also used another ATC cell line, KTC-2 cells, in which the growth inhibition by imatinib was less effective compared with FRO cells, and the potency of docetaxel was more pronounced. The combined treatment similarly inhibited cell growth, almost completely (Fig. 1). The rates of growth reduction at 4 days in docetaxel, imatinib, and combined treatment were $47.3 \%$, $68.5 \%$, and $96.0 \%$ in FRO cells and $76.1 \%, 29.6 \%$, and $99.5 \%$ in KTC-2 cells, respectively (Fig. 1).

\section{Apoptotic changes in cells treated with the drugs}

Although the degree of cell detachment was more notable in the combined treatment than in the single treatment group, we first explored the possibility of involvement of senescence-like growth arrest (SLGA) because we previously demonstrated that imatinib plus radiation therapy enhanced SLGA in ATC cells (15). Neither single treatment nor combined treatment induced SA- $\beta$-gal activity in FRO or KTC-2 cell lines, suggesting that the growth inhibitory effect was not due to SLGA (data not shown). Next, we examined whether the effect was associated with apoptosis. Cells were treated with the drugs for 16 hours and then double stained with fluorescein isothiocyanate-conjugated annexin $\mathrm{V}$ and PI to look at early apoptotic response (right lower quadrant in each dot plot in Fig. 2) and subsequent cell death (right upper quadrant). Imatinib barely caused apoptosis, and docetaxel moderately induced it. On the other hand, combined treatment further increased apoptosis (Fig. 2).
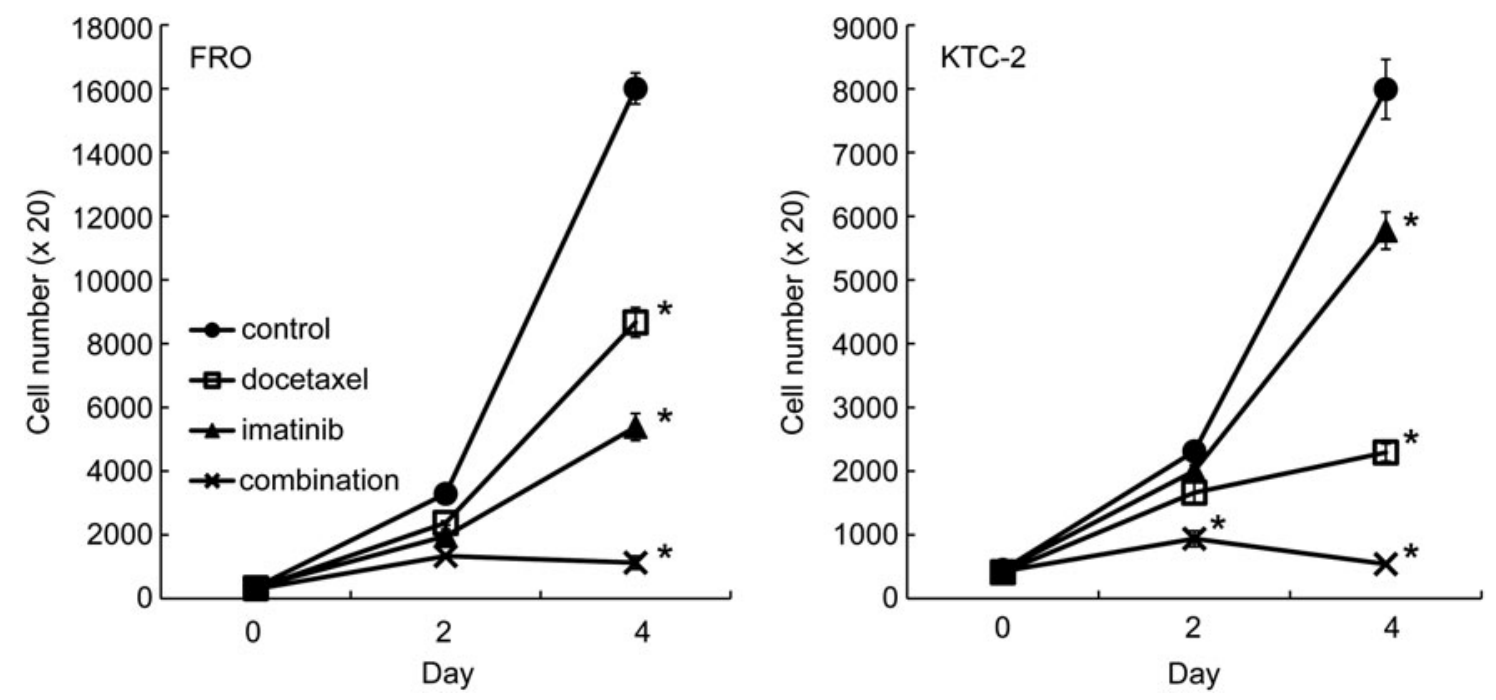

FIG. 1. Cytotoxic effect of docetaxel and/or imatinib on anaplastic thyroid cancer (ATC) cells. Growth of FRO and KTC-2 cells treated with $1 \mathrm{nM}$ of docetaxel and/or $7 \mu \mathrm{M}$ of imatinib for 2 and 4 days was determined by cell count assay. Each point represents mean \pm standard deviation. ${ }^{*} p<0.01$ versus any other group. Similar results were obtained in three independent experiments. 
FIG. 2. Apoptotic changes in cells treated with drugs. FRO cells were treated with the drugs ( $1 \mathrm{nM}$ docetaxel and/or $7 \mu \mathrm{M}$ imatinib) for 16 hours and then double stained with fluorescein isothiocyanate-conjugated annexin $\mathrm{V}$ and propidium iodide (PI), then analyzed on an FACS Vantage SE.

Fluorescein isothiocyanate and PI emissions were detected in the FL-1 and FL-3 channels, respectively. The cells in left lower, right lower, and right upper quadrant represent viable cells, early apoptotic cells, and terminal stage of apoptotic or necrotic cells, respectively. Data are representative of two independent experiments.
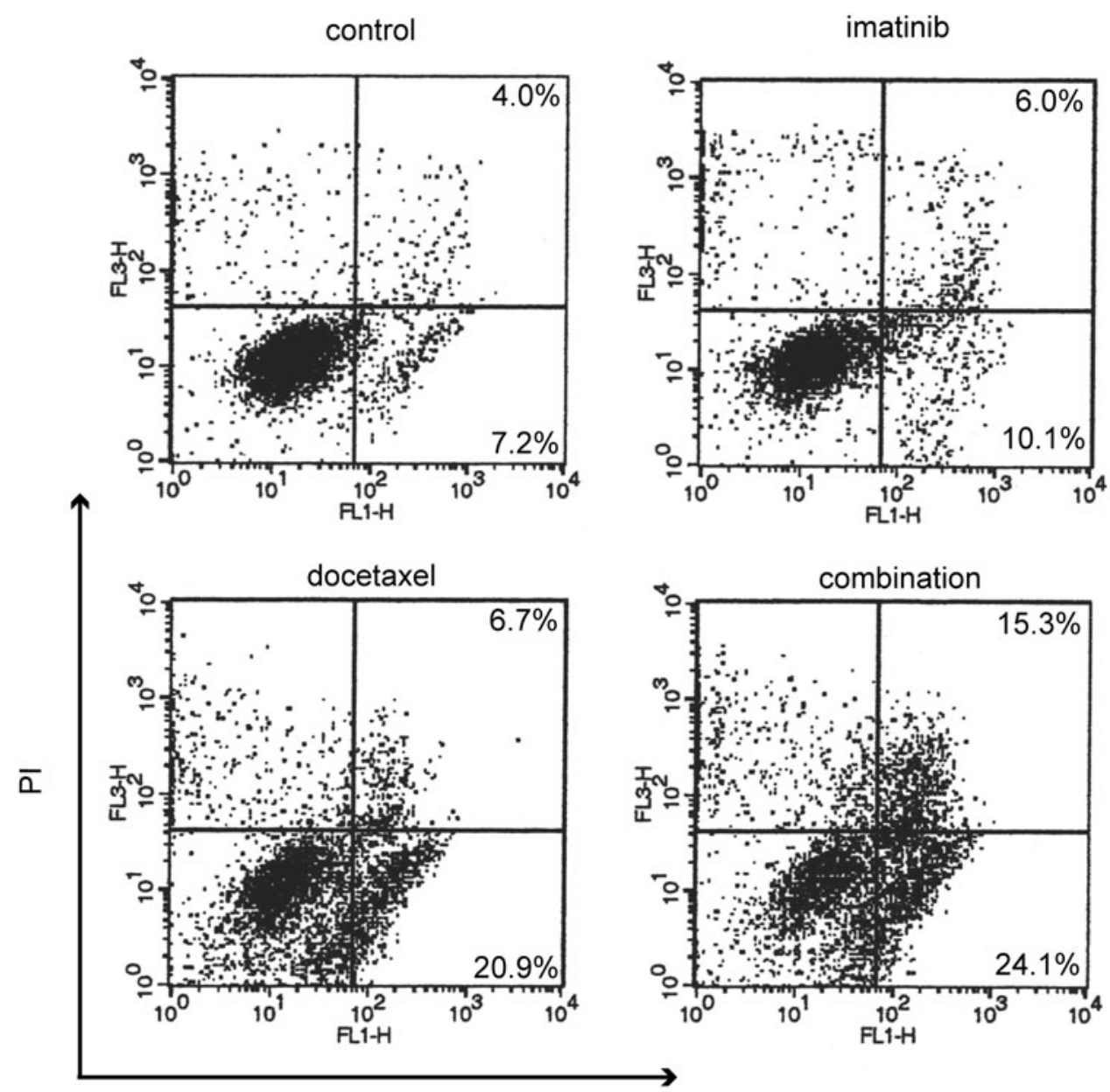

Annexin V

\section{Effects of docetaxel and imatinib on proapoptotic and antiapoptotic factors}

We next examined the status of several key proteins involved in apoptosis by Western blotting. After ATC cells were treated with docetaxel, the cleavages of caspase-3 $(19 \mathrm{kDa}$ and $17 \mathrm{kDa})$ and PARP $(89 \mathrm{kDa})$ levels were induced (Fig. 3). The cleaved PARP and caspase-3 were further increased by combined treatment, suggesting stronger apo- ptotic change (Fig. 3). XIAP and survivin belong to the human inhibitors of apoptosis (IAP) family, and their overexpression in cancer cells suggests an important role for these proteins in cancer progression. We tested whether docetaxel and/or imatinib modulate the expression of these antiapoptotic gene products by Western blotting. As shown in Fig. 3, although ATC cells themselves expressed high levels of XIAP and survivin, docetaxel further increased the levels (Fig. 3). A single treatment of imatinib did not change
FIG. 3. Effects of docetaxel and imatinib on apoptotic factors. Cells were treated with the drugs ( $4 \mathrm{nM}$ docetaxel and/or $7 \mu \mathrm{M}$ imatinib) for 16 hours [X-linked inhibitor of apoptosis (XIAP) and survivin] or 24 hours [caspase 3 and poly (ADP-ribose) polymerase (PARP)], and whole-cell lysates were examined by Western blotting. $\beta$-Actin was used as a loading control. Data are representative of at least two independent experiments.
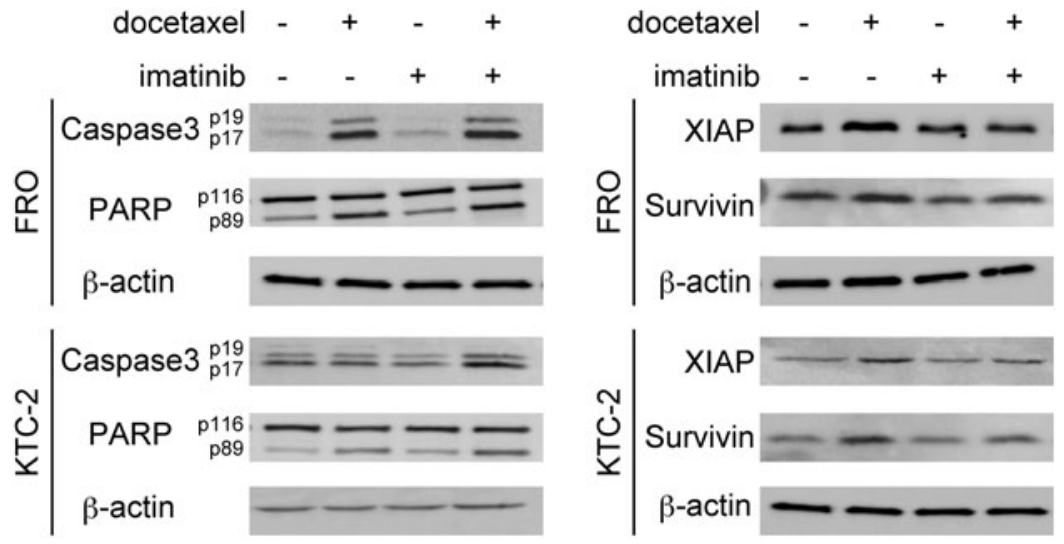
their background levels. However, the increased docetaxelinduced XIAP and survivin expression was suppressed by the combination treatment (Fig. 3).

\section{Docetaxel induces $N F-\kappa B$ activation, and imatinib inhibits the effect}

Since we already reported that the expression of those antiapoptotic factors was regulated through NF- $\kappa \mathrm{B}$ signaling pathway in ATC cells (7), we next performed DNA-binding assays using nuclear extracts to assess NF- $\kappa$ B activity. In both
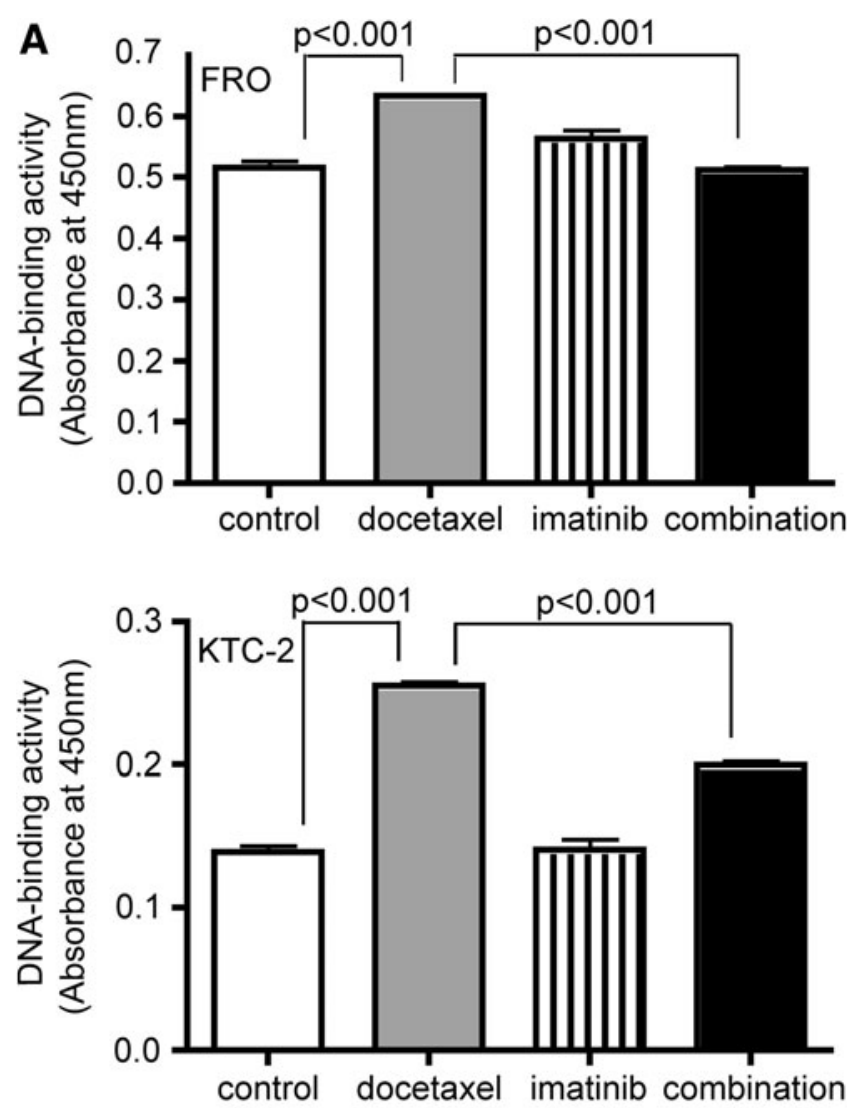

B

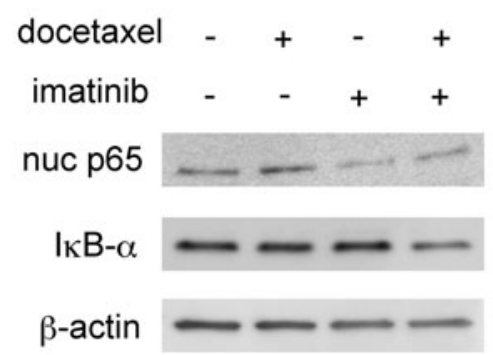

FIG. 4. Docetaxel induces nuclear factor $-\kappa \mathrm{B}(\mathrm{NF}-\kappa \mathrm{B})$ activation, and imatinib inhibits the effect. (A) Cells were treated with $4 \mathrm{nM}$ docetaxel and/or $7 \mu \mathrm{M}$ imatinib for 24 (FRO) and 48 hours (KTC-2). Nuclear extracts were prepared and subjected to DNA-binding assays. Bars represent mean \pm SD of three wells. (B) FRO cells were treated with $4 \mathrm{nM}$ docetaxel and/or $7 \mu \mathrm{M}$ imatinib for 16 hours, and then nuclear extracts (for nuclear p65) or total cell lysates (for $\mathrm{I} \kappa \mathrm{B} \alpha$ ) were examined by Western blotting. $\beta$-Actin was used as a loading control. Similar results were obtained in at least two independent experiments.
FRO and KTC-2 cell lines, the binding activity of nuclear p65 was increased by docetaxel treatment. Although imatinib alone had no effect on NF- $\kappa$ B background levels, with the combined treatment, imatinib significantly suppressed docetaxel-induced NF- $\kappa \mathrm{B}$ activation (Fig. 4A). A similar trend was observed in the amount of nuclear p65 (Fig. 4B). We also checked $\mathrm{I} \kappa \mathrm{B} \alpha$ expression. As shown in Fig. $4 \mathrm{~B}$, combined treatment reduced $\mathrm{I} \kappa \mathrm{B} \alpha$ protein level, consistent with our previous studies $(7,25)$. NF- $\kappa \mathrm{B}$ is known to bind the $\mathrm{I} \kappa \mathrm{B} \alpha$ promoter and activate its synthesis, and therefore the inhibition of NF- $\kappa \mathrm{B}$ probably suppressed de novo synthesis of $\mathrm{I} \kappa \mathrm{B} \alpha$. Presumably, for the same reason, $\mathrm{I} \kappa \mathrm{B} \alpha$ expression after docetaxel treatment was not changed (Fig. 4B).

\section{In vivo effects of the combined treatment} with docetaxel and imatinib

To explore the effects of the combined treatment in vivo, we used an animal xenograft model inoculated with FRO cells, and the treatments were done as described in the Materials and Methods section. As shown in Fig. 5, the mean tumor size of the imatinib-treated group was smaller than that of control, but this difference was not statistically significant. Although docetaxel treatment alone was able to delay tumor growth moderately, the effect of the combined treatment with docetaxel and imatinib was far greater. Body weight and physical activity of mice exposed to these drugs were not significantly affected.

\section{Discussion}

We and other groups have reported that taxanes (including paclitaxel and docetaxel) induce both pro- and antiapoptotic signaling pathways, and that antiapoptotic factors are also induced, through NF- $\kappa \mathrm{B}$ activation $(7,26,27)$. NF- $\kappa \mathrm{B}$ is a transcription factor that regulates genes involved in cellular proliferation and survival (28). In most cases, NF- $\kappa$ B suppresses apoptosis by upregulation of antiapoptotic proteins,

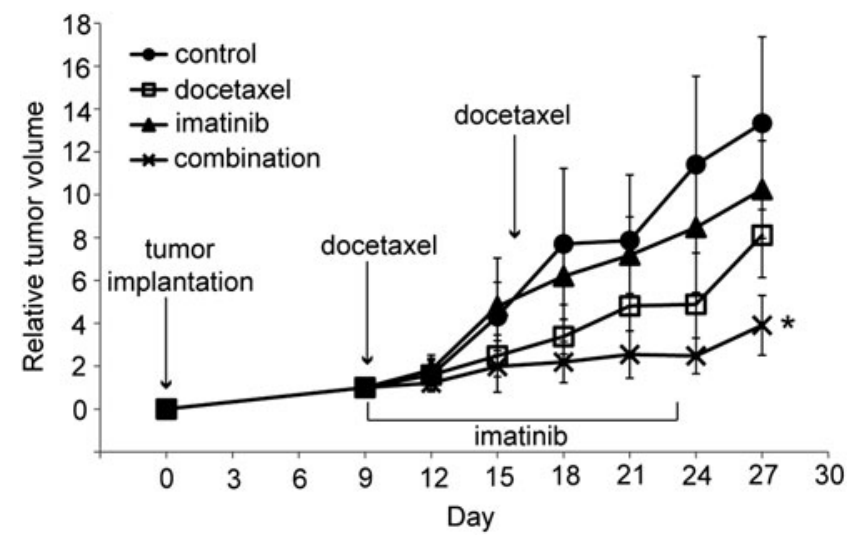

FIG. 5. Effect of docetaxel and imatinib in FRO tumor xenograft model. FRO cells were implanted and imatinib was injected i.p. at a dose of $50 \mathrm{mg} / \mathrm{kg} /$ day for 14 days, beginning on day 9 after tumor implantation. Docetaxel was injected i.p. at a dose of $5 \mathrm{mg} / \mathrm{kg}$ on days 9 and 16 . Combined treatment mice were given both drugs. Control group mice received vehicle injection only. Each point represents mean $\pm S D$ of 10 tumors (in five mice). ${ }^{*} p<0.01$ versus any other group. i.p., intraperitoneally. 
including IAP, such as c-IAP, B-cell lymphoma-extra large (BCL-xL), XIAP, and survivin $(29,30)$. In addition, basal NF- $\kappa$ B activity is often increased in various types of human cancers, which causes chemotherapy resistance (31). Under certain conditions, cytotoxic drugs, such as taxanes, induce NF- $\kappa$ B activation in different types of malignant cells $(26,32$ 36). The present data also showed that docetaxel induced NF$\kappa \mathrm{B}$ activation and then upregulated antiapoptotic factors in two ATC cell lines, FRO and KTC-2.

In our experiments, imatinib seemed to enhance apoptosis presumably through the inhibition of docetaxel-induced NF$\kappa \mathrm{B}$ activation. There are several reports proposing the mechanism by which imatinib inhibits the docetaxel-induced NF$\kappa \mathrm{B}$ activation. The phosphoinositide 3-kinase (PI3K)/AKT (also known as Protein Kinase B [PKB]) pathway has been associated with cancer cell resistance to chemotherapeutic drugs including paclitaxel $(34,37)$. Possible mechanisms of such resistance may be due to the activation of the NF- $\kappa \mathrm{B}$ pathway via PI3K/AKT activation (38). Qian et al. compared the gene expression profiles in individual human prostate cancer specimens before and after chemotherapy and showed that docetaxel treatment increased CCL2 expression (39). They also showed that upregulation of CCL2 contributed to chemotherapy resistance through stimulating mitogen-activated protein kinase and PI3K/AKT signaling pathways. Several other reports have demonstrated that imatinib inhibited the PI3K/AKT pathway, resulting in the inhibition of NF- $\kappa$ B activation in cancer cells. Fang et al. reported that imatinib induced apoptosis in BCR/ABL-positive human leukemia cells in association with the downregulation of antiapoptotic factors, such as XIAP, through the inhibition of AKT and NF- $\kappa \mathrm{B}$ activities (40). Xu et al. reported that imatinib inhibited ionizing radiation-induced RelB nuclear translocation by decreasing the phosphorylation levels of PI3K (Tyr458) and AKT (Ser473) in androgen-independent prostate cancer cells (41). They showed that imatinib inhibited PI3K tyrosine phosphorylation, leading to the downregulation of the AKT/ IKK- $\alpha$-activated NF- $\kappa \mathrm{B}$ pathway. We examined whether docetaxel and/or imatinib modulate the phosphorylation level of AKT. However, we could detect neither the activation of AKT by docetaxel treatment nor the inhibition of AKT by imatinib (data not shown). Further experiments are necessary to clarify the exact mechanism by which imatinib inhibits the docetaxel-induced NF- $\kappa$ B activation in ATC cells.

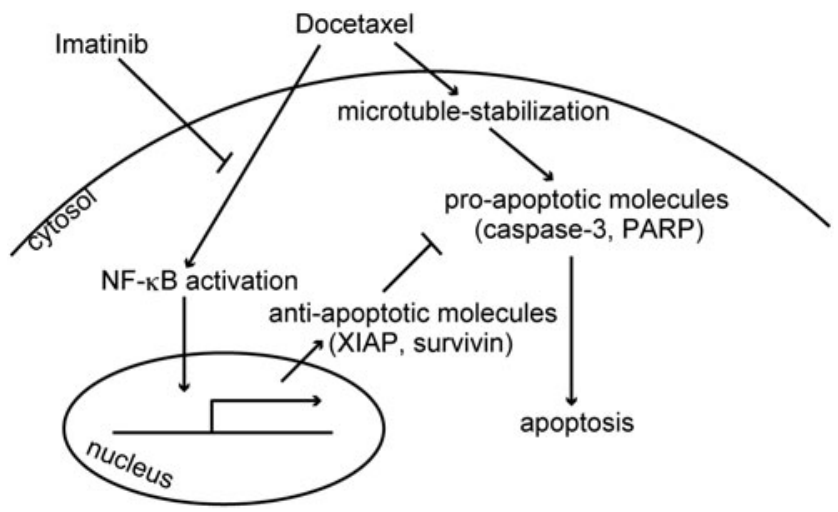

FIG. 6. A proposed mechanistic model of enhancement of docetaxel-induced apoptosis by imatinib.
Data obtained in our experiments showed that combination of docetaxel and imatinib effectively killed ATC cells, both in vitro and in vivo. Based on our and other's findings, we propose a mechanistic scheme in Fig. 6. As previously shown, docetaxel activates both proapoptotic and antiapoptotic signals. In proapoptotic pathway, docetaxel binds to microtubules, impairs mitosis, and induces apoptosis. In antiapoptotic pathway, docetaxel also induces NF- $\kappa$ B activation and in turn increases the expression of antiapoptotic molecules. Imatinib inhibits docetaxel-induced NF- $\kappa$ B activation (but does not reduce basal NF- $\kappa$ B levels, even though they are high). By this mechanism, imatinib presumably modulates the balance between pro- and antiapoptotic signals and enhances docetaxel-induced apoptosis.

In conclusion, our present study demonstrates that imatinib enhanced antitumor activity of docetaxel in ATC cells, suggesting that this combination may be a promising approach for the treatment of ATCs. Since docetaxel and imatinib have already been approved and currently being used for other type of cancers, this combination strategy can be rapidly applied in clinical trials.

\section{Acknowledgments}

This work was supported in part by Grant-in-Aid for Scientific Research (\#23591357, \#22256004, and \#22390189), Grant-in-Aid for Young Scientists (\#22791204), and Global COE Program from the Ministry of Education, Culture, Sports, Science, and Technology of Japan.

\section{Disclosure Statement}

The authors declare no conflict of interest.

\section{References}

1. Brignardello E, Gallo M, Baldi I, Palestini N, Piovesan A, Grossi E, Ciccone G, Boccuzzi G 2007 Anaplastic thyroid carcinoma: clinical outcome of 30 consecutive patients referred to a single institution in the past 5 years. Eur J Endocrinol 156:425-430.

2. Kim JC, Saha D, Cao Q, Choy H 2004 Enhancement of radiation effects by combined docetaxel and flavopiridol treatment in lung cancer cells. Radiother Oncol 71:213-221.

3. Mason KA, Hunter NR, Milas M, Abbruzzese JL, Milas L 1997 Docetaxel enhances tumor radioresponse in vivo. Clin Cancer Res 3:2431-2438.

4. Reiner T, de las Pozas A, Gomez LA, Perez-Stable C 2009 Low dose combinations of 2-methoxyestradiol and docetaxel block prostate cancer cells in mitosis and increase apoptosis. Cancer Lett 276:21-31.

5. Kawada K, Kitagawa K, Kamei S, Inada M, Mitsuma A, Sawaki M, Kikumori T, Fujimoto Y, Arima H, Imai T, Ando Y 2010 The feasibility study of docetaxel in patients with anaplastic thyroid cancer. Jpn J Clin Oncol 40:596-599.

6. Foote RL, Molina JR, Kasperbauer JL, Lloyd RV, McIver B, Morris JC, Grant CS, Thompson GB, Richards ML, Hay ID, Smallridge RC, Bible KC 2011 Enhanced survival in locoregionally confined anaplastic thyroid carcinoma: a singleinstitution experience using aggressive multimodal therapy. Thyroid 21:25-30.

7. Meng Z, Mitsutake N, Nakashima M, Starenki D, Matsuse M, Takakura S, Namba H, Saenko V, Umezawa K, Ohtsuru A, Yamashita S 2008 Dehydroxymethylepoxyquinomicin, a 
novel nuclear factor-kappaB inhibitor, enhances antitumor activity of taxanes in anaplastic thyroid cancer cells. Endocrinology 149:5357-5365.

8. Troch M, Koperek O, Scheuba C, Dieckmann K, Hoffmann M, Niederle B, Raderer M 2010 High efficacy of concomitant treatment of undifferentiated (anaplastic) thyroid cancer with radiation and docetaxel. J Clin Endocrinol Metab 95:E54-E57.

9. Bellone G, Ferrero D, Carbone A, De Quadros MR, Gramigni C, Prati A, Davidson W, Mioli P, Dughera L, Emanuelli G, Rodeck U 2004 Inhibition of cell survival and invasive potential of colorectal carcinoma cells by the tyrosine kinase inhibitor STI571. Cancer Biol Ther 3:385-392.

10. Buchdunger E, O'Reilly T, Wood J 2002 Pharmacology of imatinib (STI571). Eur J Cancer 38 Suppl 5:S28-S36.

11. Dagher R, Cohen M, Williams G, Rothmann M, Gobburu J, Robbie G, Rahman A, Chen G, Staten A, Griebel D, Pazdur R 2002 Approval summary: imatinib mesylate in the treatment of metastatic and/or unresectable malignant gastrointestinal stromal tumors. Clin Cancer Res 8:3034-3038.

12. Deininger M, Buchdunger E, Druker BJ 2005 The development of imatinib as a therapeutic agent for chronic myeloid leukemia. Blood 105:2640-2653.

13. Matei D, Chang DD, Jeng MH 2004 Imatinib mesylate (Gleevec) inhibits ovarian cancer cell growth through a mechanism dependent on platelet-derived growth factor receptor alpha and Akt inactivation. Clin Cancer Res 10:681690.

14. Podtcheko A, Ohtsuru A, Tsuda S, Namba H, Saenko V, Nakashima M, Mitsutake N, Kanda S, Kurebayashi J, Yamashita S 2003 The selective tyrosine kinase inhibitor, STI571, inhibits growth of anaplastic thyroid cancer cells. J Clin Endocrinol Metab 88:1889-1896.

15. Podtcheko A, Ohtsuru A, Namba H, Saenko V, Starenki D, Palona I, Sedliarou I, Rogounovitch T, Yamashita S 2006 Inhibition of ABL tyrosine kinase potentiates radiationinduced terminal growth arrest in anaplastic thyroid cancer cells. Radiat Res 165:35-42.

16. Ha HT, Lee JS, Urba S, Koenig RJ, Sisson J, Giordano T, Worden FP 2010 A phase II study of imatinib in patients with advanced anaplastic thyroid cancer. Thyroid 20:975980.

17. Zhang P, Gao WY, Turner S, Ducatman BS 2003 Gleevec (STI-571) inhibits lung cancer cell growth (A549) and potentiates the cisplatin effect in vitro. Mol Cancer 2:1.

18. Vlahovic G, Ponce AM, Rabbani Z, Salahuddin FK, Zgonjanin L, Spasojevic I, Vujaskovic Z, Dewhirst MW 2007 Treatment with imatinib improves drug delivery and efficacy in NSCLC xenografts. Br J Cancer 97:735-740.

19. Gucluler G, Baran Y 2009 Docetaxel enhances the cytotoxic effects of imatinib on Philadelphia positive human chronic myeloid leukemia cells. Hematology 14:139-144.

20. Kinsella P, Clynes M, Amberger-Murphy V 2011 Imatinib and docetaxel in combination can effectively inhibit glioma invasion in an in vitro 3D invasion assay. J Neurooncol 101:189-198.

21. Daniels CE, Wilkes MC, Edens M, Kottom TJ, Murphy SJ, Limper AH, Leof EB 2004 Imatinib mesylate inhibits the profibrogenic activity of TGF-beta and prevents bleomycin-mediated lung fibrosis. J Clin Invest 114:13081316.

22. Kurebayashi J, Otsuki T, Tanaka K, Yamamoto Y, Moriya T, Sonoo H 2003 Medroxyprogesterone acetate decreases secretion of interleukin- 6 and parathyroid hormone-related protein in a new anaplastic thyroid cancer cell line, KTC-2. Thyroid 13:249-258.

23. Dimri GP, Lee X, Basile G, Acosta M, Scott G, Roskelley C, Medrano EE, Linskens M, Rubelj I, Pereira-Smith O, Peacocke M, Campisi J 1995 A biomarker that identifies senescent human cells in culture and in aging skin in vivo. Proc Natl Acad Sci USA 92:9363-9367.

24. Renard P, Ernest I, Houbion A, Art M, Le Calvez H, Raes M, Remacle J 2001 Development of a sensitive multi-well colorimetric assay for active NFkappaB. Nucleic Acids Res 29:E21.

25. Starenki DV, Namba H, Saenko VA, Ohtsuru A, Maeda S, Umezawa K, Yamashita S 2004 Induction of thyroid cancer cell apoptosis by a novel nuclear factor kappaB inhibitor, dehydroxymethylepoxyquinomicin. Clin Cancer Res 10:68216829.

26. Dong QG, Sclabas GM, Fujioka S, Schmidt C, Peng B, Wu T, Tsao MS, Evans DB, Abbruzzese JL, McDonnell TJ, Chiao PJ 2002 The function of multiple IkappaB: NF-kappaB complexes in the resistance of cancer cells to taxol-induced apoptosis. Oncogene 21:6510-6519.

27. Pushkarev VM, Starenki DV, Saenko VA, Namba H, Kurebayashi J, Tronko MD, Yamashita S 2004 Molecular mechanisms of the effects of low concentrations of taxol in anaplastic thyroid cancer cells. Endocrinology 145:31433152.

28. Barkett M, Gilmore TD 1999 Control of apoptosis by Rel/ NF-kappaB transcription factors. Oncogene 18:6910-6924.

29. Lee R, Collins T 2001 Nuclear factor-kappaB and cell survival: IAPs call for support. Circ Res 88:262-264.

30. Stehlik C, de Martin R, Kumabashiri I, Schmid JA, Binder BR, Lipp J 1998 Nuclear factor (NF)-kappaB-regulated Xchromosome-linked iap gene expression protects endothelial cells from tumor necrosis factor alpha-induced apoptosis. J Exp Med 188:211-216.

31. Rayet B, Gelinas C 1999 Aberrant rel/nfkb genes and activity in human cancer. Oncogene 18:6938-6947.

32. Aggarwal BB, Shishodia S, Takada Y, Banerjee S, Newman RA, Bueso-Ramos CE, Price JE 2005 Curcumin suppresses the paclitaxel-induced nuclear factor-kappaB pathway in breast cancer cells and inhibits lung metastasis of human breast cancer in nude mice. Clin Cancer Res 11:7490-7498.

33. Domingo-Domenech J, Oliva C, Rovira A, Codony-Servat J, Bosch M, Filella X, Montagut C, Tapia M, Campas C, Dang L, Rolfe M, Ross JS, Gascon P, Albanell J, Mellado B 2006 Interleukin 6, a nuclear factor-kappaB target, predicts resistance to docetaxel in hormone-independent prostate cancer and nuclear factor-kappaB inhibition by PS-1145 enhances docetaxel antitumor activity. Clin Cancer Res 12:5578-5586.

34. Mabuchi S, Ohmichi M, Nishio Y, Hayasaka T, Kimura A, Ohta T, Kawagoe J, Takahashi K, Yada-Hashimoto N, SeinoNoda H, Sakata M, Motoyama T, Kurachi H, Testa JR, Tasaka K, Murata Y 2004 Inhibition of inhibitor of nuclear factor-kappaB phosphorylation increases the efficacy of paclitaxel in in vitro and in vivo ovarian cancer models. Clin Cancer Res 10:7645-7654.

35. Nakahara C, Nakamura K, Yamanaka N, Baba E, Wada M, Matsunaga H, Noshiro H, Tanaka M, Morisaki T, Katano M 2003 Cyclosporin-A enhances docetaxel-induced apoptosis through inhibition of nuclear factor-kappaB activation in human gastric carcinoma cells. Clin Cancer Res 9:5409-5416.

36. Zhang $H$, Morisaki $T$, Nakahara C, Matsunaga $H$, Sato N, Nagumo F, Tadano J, Katano M 2003 PSK-mediated NF-kap- 
paB inhibition augments docetaxel-induced apoptosis in human pancreatic cancer cells NOR-P1. Oncogene 22:20882096.

37. West KA, Castillo SS, Dennis PA 2002 Activation of the PI3K/Akt pathway and chemotherapeutic resistance. Drug Resist Update 5:234-248.

38. Sizemore N, Leung S, Stark GR 1999 Activation of phosphatidylinositol 3-kinase in response to interleukin-1 leads to phosphorylation and activation of the NF-kappaB p65/ RelA subunit. Mol Cell Biol 19:4798-4805.

39. Qian DZ, Rademacher BL, Pittsenbarger J, Huang CY, Myrthue A, Higano CS, Garzotto M, Nelson PS, Beer TM 2010 CCL2 is induced by chemotherapy and protects prostate cancer cells from docetaxel-induced cytotoxicity. Prostate 70:433-442.

40. Fang G, Kim CN, Perkins CL, Ramadevi N, Winton E, Wittmann S, Bhalla KN 2000 CGP57148B (STI-571) induces differentiation and apoptosis and sensitizes Bcr-Abl-positive human leukemia cells to apoptosis due to antileukemic drugs. Blood 96:2246-2253.

41. Xu Y, Fang F, Sun Y, St. Clair DK, St. Clair WH 2010 RelBdependent differential radiosensitization effect of STI571 on prostate cancer cells. Mol Cancer Ther 9:803-812.

Address correspondence to: Norisato Mitsutake, M.D., Ph.D. Department of Radiation Medical Sciences

Atomic Bomb Disease Institute

Nagasaki University Graduate School of Biomedical Sciences 1-12-4 Sakamoto

Nagasaki 852-8523

Japan

E-mail: mitsu@nagasaki-u.ac.jp 